\title{
Temporal and spatial variation of the pollinator assemblages in Alstroemeria ligtu (Alstroemeriaceae)
}

\author{
Alejandra V González ${ }^{1 *}$, Maureen Murúa ${ }^{1,2}$ and Patricia A Ramírez ${ }^{1,3}$
}

\section{Findings}

Plant-pollinator interactions have been seen as a coadaptative process between pollinators and flowers (Johnson and Steiner 2000). Even though specialized pollinator systems do exist, most plants are pollinated by a wide spectrum of pollinators (Ollerton 1996; Waser et al. 1996). Accordantly, the degree of generalization in a plantpollinator system may vary temporally and spatially in relation to biotic or abiotic environment fluctuations (see Gómez and Perfectti 2009, for review). In general, spatial variation has been invoked as the most important factor in the maintenance of generalization (Herrera 1996; Fenster et al. 2004), and temporal variation has been underlooked (but see Williams et al. 2001; Gómez 2002). In the long run, pollinator variation can be translated into interpopulation variation in the degree of generalization, which subsequently can affect the reproductive success of plant species (Suárez et al. 2009; Botto-Mahan et al. 2011).

Alstroemeria ligtu var. simsii Sprengel (Alstroemeriaceae) is a perennial herb endemic to central Chile (Muñoz and Moreira 2003). A. ligtu simsii is a hermaphroditic selfincompatible subspecies that relies entirely on pollinators for reproduction (Arroyo and Uslar 1993). The zygomorphic flowers are 4 to $6 \mathrm{~cm}$ long and arranged in umbels with one to four flowers each. The flowers consist of four red tepals, two distinctive yellow tepals streaked with brownish lines (Figure 1A). The flowering season extends from November to January, following by the fruiting season that ends in February (Arroyo and Uslar 1993; Botto-Mahan et al. 2011).

The study was carried out during two austral spring seasons (2011 and 2012), in six populations that comprise most of the distributional range of $A$. ligtu simsii from central Chile (Figure 1B). The region is characterized by a

\footnotetext{
* Correspondence: apgonzalez@uchile.cl

1 Departamento de Ciencias Ecológicas, Facultad de Ciencias, Universidad de Chile, Casilla 653, Santiago 7800003, Chile

Full list of author information is available at the end of the article
}

Mediterranean-type climate (di Castri and Hajek 1976), where populations were exposed to similar variation of temperature and precipitation (considering maximum and minimum of both abiotic variables in the warmest, coldest, wettest, and driest months), which did not differ significantly among them (temperature: $F_{5,35}=0.55$, $P=0.73$; precipitation: $F_{5,35}=0.30, P=0.90$ ). In every year, 74 to 200 plants per population were tagged, and pollinator assemblages were characterized in terms of abundance and diversity. Due to floral phenology occurring at the same time in each location (November to December) for both years, each population was sampled in the same week, repeating this procedure for three consecutive weeks until covering the whole flowering period. Only floral visitors that contacted plant reproductive structures were considerate as legitimate pollinators. We registered pollinator frequency in 15min census between 1000 to 1700 hours in a total of 2,157 focal plants. The pollinators were identified at the highest resolution possible and classified at functional groups (Fenster et al. 2004). Then, visit rate (number of visits per plant per hour), species richness (S), and Shannon diversity index $\left(H^{\prime}\right)$ were estimated for each population and year in the PAST software version 2.17 (Hammer et al. 2001). Additionally, we compared similarity in the pollinator assemblage composition, based on proportional visitation data, which takes into account both the identity of pollinators and their relative abundance. We used cluster analyses with Euclidean distance in the PAST software. Finally, we correlated pollinator composition matrix (PM) between the two studied seasons with the geographic distance matrix (GM), using Mantel test in the PAST software using 10,000 iterations.

Pollinator assemblages varied both temporally and spatially. First, during the 2011 season, we registered a total of 24 pollinator species and 2,137 visits. Considering all populations together, pollinator assemblages were 


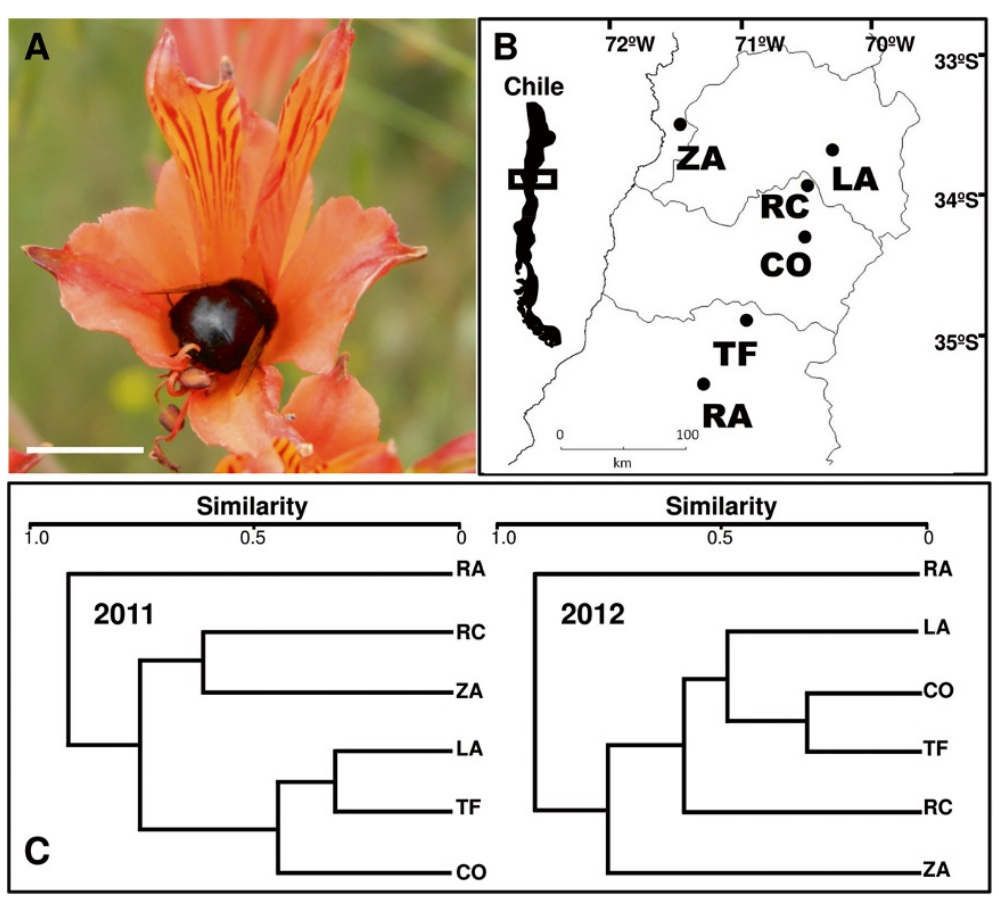

Figure 1 A. ligtu simsii, geographical distribution, and dendrogram. (A) A. ligtu simsii pollinated by L. corvina, scale bar $=1.5 \mathrm{~cm}$. (B) Geographical distribution of the studied populations. (C) Dendrogram showing similarity of pollinator assemblage between flowering seasons 2011 and 2012.

composed by three functional groups: Diptera (50.5\% of visits), Hymenoptera (39.9\% of visits), and Lepidoptera (9.4\% of visits, Table 1$)$. However, Hymenoptera was the functional group with the highest richness (Table 1). By contrast, during the 2012 season, 29 pollinator species were registered, but only 1,069 visits with different percentages of representation. Specifically, Hymenoptera increased its contribution (64.2\% of visits), whereas Diptera and Lepidoptera decreased their relative importance in the total assemblage with respect to the previous year (33.8\% and $2.1 \%$ of visits, respectively). Notwithstanding, Hymenoptera remained as the functional group with the highest richness, with Centris nigerrima being the only pollinator shared by all populations of $A$. ligtu simsii in both flowering seasons (Table 1). Second, in the 2011 season, the visit rate, species richness, and species diversity differed among populations (Table 1). For example, population TF (see table of population abbreviations) showed the highest visit rate, but ZA population showed the highest richness and LA the highest diversity $\left(H^{\prime}\right)$ values. The similarity analyses (Figure $1 C$ ) showed that RA was the most dissimilar population. Otherwise, we observed two clusters of population: the first group was composed by LA, TF, and CO, with distance of similitude ranging from 0.20 to 0.44 . Populations RC and LA formed the second group with 0.61 of distance of similitude. However, this similarity did not show a latitudinal pattern (Mantel test: $\mathrm{PM}_{2011}$ vs. GM: $\left.r_{\mathrm{m}}=0.02, P=0.43\right)$. In the same way, for the 2012 season, populations also differed in the pollinator assemblage composition. For example, TF reduced ten times its visitation rate with respect to 2011 (from 20.7 to 1.92 , respectively), and the ZA population showed the highest richness, and $\mathrm{CO}$ the highest $H^{\prime}$ values. During 2012, RA remains as the most dissimilar population, even though the rest of the populations belong to one cluster only; the populations LA, TF, and CO maintained their range of similarity $(0.27$ to 0.50$)$ compared to the other populations (Figure 1C). In this flowering season, no latitudinal pattern was observed in the similarity of pollinator composition (Mantel test: $\mathrm{PM}_{2012}$ vs. GM: $\left.r_{\mathrm{m}}=0.35, P=0.08\right)$.

Overall, our results showed that $A$. ligtu simsii is a generalist plant with 4 to 16 different pollinator species. Consistently, we found that pollinator abundance, richness, and diversity were different among populations and years. This scenario is particularly important if we consider that plants of $A$. ligtu simsii necessarily require a pollinator agent to transport pollen from anthers to stigmas. In this context, temporal and spatial variations in the pollinator assemblages of $A$. ligtu simsii may determine the reproductive success of individuals, populations, and consequently the maintenance of this subspecies. 
Table 1 Temporal and spatial variation of pollinator assemblages in A. ligtu simsii

\begin{tabular}{|c|c|c|c|c|c|c|c|c|c|c|c|c|}
\hline \multirow[t]{4}{*}{ Pollinators } & \multicolumn{12}{|c|}{ Visitation rate $\left(\mathrm{V} r\right.$, visits flower $\left.{ }^{-1} h^{-1}\right)$} \\
\hline & \multicolumn{6}{|c|}{2011} & \multicolumn{6}{|c|}{2012} \\
\hline & ZA & LA & RC & $\mathrm{CO}$ & TF & RT & ZA & LA & RC & $\mathrm{CO}$ & TF & RT \\
\hline & $N=180$ & $N=180$ & $N=240$ & $N=125$ & $N=74$ & $N=178$ & $N=200$ & $N=150$ & $N=200$ & $N=200$ & $N=200$ & $N=200$ \\
\hline \multicolumn{13}{|l|}{ Diptera } \\
\hline Diptera sp.1 & 0.09 & 0 & 0 & 0 & 0 & 0 & 0 & 0 & 0 & 0.02 & 0 & 0 \\
\hline Diptera sp.2 & 0 & 0.56 & 0 & 0 & 0 & 0 & 0 & 0 & 0 & 0 & 0 & 0 \\
\hline Diptera sp.3 & 0 & 0.07 & 0 & 0 & 0 & 0 & 0 & 0 & 0 & 0 & 0 & 0 \\
\hline Diptera sp.4 & 0 & 0.13 & 0 & 0 & 0 & 0 & 0 & 0 & 0 & 0 & 0 & 0 \\
\hline Lasia aenea & 1.71 & 0.09 & 0.03 & 0 & 0 & 0 & 2.04 & 0 & 0.04 & 0 & 0 & 0 \\
\hline Lasia corvina & 0.73 & 6.22 & 0 & 10.53 & 10.3 & 0 & 0.14 & 2.61 & 0 & 1.56 & 0.96 & 0 \\
\hline Mycteromia sp. & 0 & 0.04 & 0.32 & 0.58 & 4.86 & 0 & 0 & 0.03 & 0 & 0.30 & 0 & 0.18 \\
\hline Vr (Diptera) & 2.53 & 7.11 & 0.35 & 11.11 & 15.1 & 0 & 2.18 & 2.64 & 0.04 & 1.88 & 0.96 & 0.18 \\
\hline S (Diptera) & 3 & 6 & 2 & 2 & 2 & 0 & 2 & 2 & 1 & 3 & 1 & 1 \\
\hline$H^{\prime}$ (Diptera) & 0.74 & 0.52 & 0.31 & 0.20 & 0.63 & 0 & 0.24 & 0.06 & 0 & 0.49 & 0 & 0 \\
\hline \multicolumn{13}{|l|}{ Hymenoptera } \\
\hline Alloscirtetica gayi & 0.22 & 1.02 & 1.17 & 0 & 2.70 & 0 & 0.02 & 3.17 & 0.46 & 0.46 & 0.14 & 0.06 \\
\hline Andrenido sp.1 & 0 & 0 & 0 & 0 & 0 & 0 & 0.22 & 0 & 0 & 0 & 0.04 & 0 \\
\hline Apis mellifera & 0.67 & 0.51 & 0.12 & 0.51 & 0 & 0 & 0 & 0 & 0 & 0 & 0 & 0 \\
\hline Bombus ruderatus & 0 & 0 & 0 & 0 & 0 & 0 & 0 & 0 & 0 & 0 & 0 & 3.06 \\
\hline Bombus terrestris & 0 & 0 & 0 & 0 & 0 & 0 & 0 & 0 & 0 & 0 & 0 & 0.06 \\
\hline Caenohalictus sp. & 0 & 0 & 0 & 0 & 0.70 & 0 & 0 & 0 & 0 & 0 & 0 & 0 \\
\hline Centris nigerrima & 1.09 & 0.60 & 0.20 & 0 & 0.32 & 1.57 & 0.46 & 0.61 & 0.38 & 0.32 & 0.32 & 0.08 \\
\hline Cerceris gayi & 0 & 0 & 0 & 0 & 0 & 0 & 0.02 & 0 & 0 & 0 & 0 & 0 \\
\hline Corynura sp. & 0 & 0 & 0 & 0.13 & 0 & 0 & 0 & 0 & 0 & 0 & 0 & 0 \\
\hline Epiclopus sp. & 0 & 0.76 & 0 & 0 & 0 & 0 & 0 & 0 & 0 & 0 & 0 & 0 \\
\hline Halictido sp.1 & 0 & 0 & 0.08 & 0 & 0 & 0 & 0 & 0 & 0 & 0 & 0 & 0 \\
\hline Lasioglossum sp. & 0 & 0 & 0 & 0 & 1.19 & 0.25 & 0 & 0 & 0 & 0.08 & 0 & 0 \\
\hline Manuelia gayi & 0.96 & 0.24 & 2.37 & 0.22 & 0.32 & 0 & 0.14 & 0 & 0.08 & 0.18 & 0 & 0.18 \\
\hline Megachile sp. & 0.11 & 0 & 0.22 & 0.10 & 0 & 0.20 & 0 & 0 & 0 & 0.08 & 0.02 & 0.02 \\
\hline Mesonychium gayi & 0 & 0 & 0.20 & 0 & 0 & 0 & 0 & 0.05 & 0.04 & 0 & 0.36 & 0 \\
\hline Ruizantheda mutabilis & 0.13 & 0.02 & 0.02 & 0 & 0 & 0 & 0 & 0.16 & 0 & 0.46 & 0 & 0 \\
\hline Ruizantheda proxima & 0.22 & 1.02 & 1.17 & 0 & 2.70 & 0 & 0.02 & 3.17 & 0.46 & 0.46 & 0.14 & 0.06 \\
\hline Svastrides melanura & 0 & 0 & 0 & 0 & 0 & 0 & 0.22 & 0 & 0 & 0 & 0.04 & 0 \\
\hline Trichothurgus sp. & 0.67 & 0.51 & 0.12 & 0.51 & 0 & 0 & 0 & 0 & 0 & 0 & 0 & 0 \\
\hline $\operatorname{Vr}$ (Hymenoptera) & 3.49 & 4.62 & 4.45 & 0.99 & 5.41 & 2.02 & 1.02 & 6.96 & 1.18 & 1.58 & 0.96 & 3.76 \\
\hline S (Hymenoptera) & 7 & 7 & 9 & 5 & 6 & 3 & 6 & 5 & 6 & 6 & 7 & 7 \\
\hline$H^{\prime}$ (Hymenoptera) & 1.66 & 1.68 & 1.38 & 1.28 & 1.39 & 0.68 & 1.41 & 1.06 & 1.47 & 1.59 & 1.48 & 0.76 \\
\hline \multicolumn{13}{|l|}{ Lepidoptera } \\
\hline Elina sp. & 0.09 & 0.69 & 0 & 0 & 0 & 0 & 0.02 & 0.11 & 0 & 0 & 0 & 0 \\
\hline Nymphalido sp.1 & 0 & 0.22 & 0 & 0 & 0 & 0 & 0.02 & 0 & 0 & 0 & 0 & 0 \\
\hline Phoebis mercedis & 3.36 & 0.04 & 0 & 0 & 0.11 & 0.02 & 0.16 & 0.16 & 0 & 0.04 & 0 & 0 \\
\hline Vr (Lepidoptera) & 3.45 & 0.96 & 0 & 0 & 0.11 & 0.02 & 0.20 & 0.27 & 0 & 0.04 & 0 & 0 \\
\hline S (Lepidoptera) & 2 & 3 & 0 & 0 & 1 & 1 & 3 & 2 & 0 & 1 & 0 & 0 \\
\hline$H^{\prime}$ (Lepidoptera) & 0.11 & 0.71 & 0 & 0 & 0 & 0 & 0.64 & 0.67 & 0 & 0 & 0 & 0 \\
\hline
\end{tabular}


Table 1 Temporal and spatial variation of pollinator assemblages in A. ligtu simsii (Continued)

\begin{tabular}{|c|c|c|c|c|c|c|c|c|c|c|c|c|}
\hline \multicolumn{13}{|l|}{ Total } \\
\hline $\mathrm{Vr}$ & 9.47 & 12.69 & 4.80 & 12.10 & 20.70 & 2.04 & 3.40 & 9.87 & 1.22 & 3.50 & 1.92 & 3.94 \\
\hline$S$ & 12 & 16 & 11 & 7 & 9 & 4 & 11 & 9 & 7 & 10 & 8 & 8 \\
\hline$H^{\prime}$ & 1.94 & 1.85 & 1.56 & 0.57 & 1.43 & 0.73 & 1.43 & 1.48 & 1.57 & 1.73 & 1.43 & 0.91 \\
\hline
\end{tabular}

ZA, Zapata; LA, Lagunillas; RC, Río Clarillo; CO, Coya; TF, Termas del Flaco; RT, Radal Siete Tazas; Vr, visitation rate; S, richness; H', Shannon diversity.

\section{Competing interests}

The authors declare that they have no competing interests.

\section{Authors' contributions}

AG conceived of the study, participated in its design, coordination and drafted the manuscript. MM and PR participated in the data analyses and drafted the manuscript. All authors read and approved the final manuscript.

\section{Acknowledgements}

We thank CONAF for the sampling permission, grant FONDECYT 11110120 to AG. The authors also thank suggestions by Dr. E Gianoli.

\section{Author details}

'Departamento de Ciencias Ecológicas, Facultad de Ciencias, Universidad de Chile, Casilla 653, Santiago 7800003, Chile. ${ }^{2}$ Fundación Jardín Botánico Nacional, Calle Camino el Olivar 305, Viña del Mar, Chile. ${ }^{3}$ School of Biological Sciences, Victoria University of Wellington, Wellington 6140, New Zealand.

Received: 2 December 2013 Accepted: 31 December 2013

Published: 26 March 2014

\section{References}

Arroyo MTK, Uslar P (1993) Breeding systems in a temperate Mediterranean-type climate montane sclerophyllous forest in central Chile. Bot J Linn Soc 111:83-102

Botto-Mahan C, Ramírez PA, Ossa CG, Medel R, Ojeda-Camacho M, González AV (2011) Floral herbivory affects female reproductive success and pollinator visitation in the perennial herb Alstroemeria ligtu (Alstroemeriaceae). Int J Plant Sci 172:1130-1136

Castri F, Hajek ER (1976) Bioclimatología de Chile. Ediciones de la Universidad Católicade. Chile, Santiago

Fenster CB, Armbruster WS, Wilson P, Dudash MR, Thomson JD (2004) Pollination syndromes and floral specialization. Annu Rev Ecol Evol Syst 35:375-403

Gómez JM, Perfectti F (2009) Diversidad de polinizadores, generalización ecológica y conservación de plantas. In: Medel R, Aizen MA, Zamora R (eds) Ecología y evolución de interacciones planta-animal. Editorial Universitaria, Santiago, pp 61-76

Gómez JM (2002) Generalización en las interacciones entre plantas y polinizadores. Rev Chil Hist Nat 75:105-116

Hammer O, Harper D, Ryan P (2001) PAST: Paleontological Statistics Software for education and data analysis. Paleontología Electrónica 4:1-9

Herrera CM (1996) Floral traits and plant adaptation to insect pollinators: a devil's advocate approach. In: Lloyd DG, Barrett SCH (eds) Floral biology: studies on floral evolution in animal-pollinated plants. Chapman \& Hall, New York, pp 65-87

Johnson SD, Steiner KE (2000) Generalization versus specialization in plant pollination systems. Trends Ecol Evol 15:140-143

Muñoz M, Moreira MA (2003) Alstroemerias de Chile: Diversidad. Distribución y Conservación, Taller La Era, Santiago, Chile
Ollerton J (1996) Reconciling ecological process with phylogenetic patterns: the apparent paradox of plant-pollinator systems. J Ecol 84:767-769

Suárez LH, González WL, Gianoli E (2009) Foliar damage modifies floral attractiveness to pollinators in Alstroemeria exerens. Evol Ecol 23:545-555

Waser NM, Chittka L, Price MV, Williams NM, Ollerton J (1996) Generalization in pollination systems, and why it matters. Ecology 77:1043-1060

Williams NM, Minckley RL, Silveira FA (2001) Variation in native bee faunas and its implications for detecting community changes. Conserv Ecol 5:7

doi:10.1186/0717-6317-87-5

Cite this article as: González et al:: Temporal and spatial variation of the pollinator assemblages in Alstroemeria ligtu (Alstroemeriaceae). Revista

Chilena de Historia Natural 2014 87:5.

\section{Submit your manuscript to a SpringerOpen ${ }^{\circ}$ journal and benefit from:}

- Convenient online submission

- Rigorous peer review

- Immediate publication on acceptance

- Open access: articles freely available online

- High visibility within the field

- Retaining the copyright to your article

Submit your next manuscript at $>$ springeropen.com 